\title{
Abundance and Diversity of Coral Reef Fish Larvae at Hurghada, Egyptian Red Sea
}

\section{Mohamed Abu El-Regal ${ }^{1}$; Ashraf I. Ahmed ${ }^{2}$; Salah G. El-Etreby ${ }^{2}$; Mohamed ElKomi ${ }^{1}$ and Michael Elliott ${ }^{3}$}

1- National Institute of Oceanography \& Fisheries, Egypt

2- Suez Canal University, Faculty of science, Marine Science Dept. Ismailia, Egypt

3- Institute of Estuarine \& Coastal Studies, University of Hull, Hull, HU6 7RX, UK.

\begin{abstract}
The larvae of coral reef fishes have been studied in Hurghada at the Egyptian Red Sea on exposed and sheltered inshore and offshore sites. Ichthyoplankton samples were taken by plankton net of $0.5 \mathrm{~mm}$ mesh size on a monthly basis from January to December 2005. The total abundance of fish larvae at all sites was $1993 / 1000 \mathrm{~m}^{3}$. There were significant differences in larval abundance between sites and months. The sheltered inshore site (H3) showed a significantly higher abundance of all sites, whereas the exposed inshore Abu Sadaf site had the lowest abundance. The most abundant 10 taxa were Atherinomorus lacunosus (Atherinidae), Spratelloides delicatulus (Clupeidae), Gerres oyena (Gerreidae), Hypoatherina temmincki (Atherinidae), Petroscirtes mitratus (Blennidae), Vinciguerria mabahiss (Phosichthyidae), Enneapterygius sp. (Triptrygiidae), Mulloides flavolineatus (Mullidae), Benthosema pterotum (Myctophidae) and Gobiidae, forming about $82.5 \%$ of all collected larvae. The most dominant species was Atherinomorus lacunosus, contributing 19\% of all taxa with a total abundance of $11 \%$ larvae $/ 1000 \mathrm{~m}^{3}$. Larvae of families Siganidae and Soleidae were the least abundant both with 0.23 larvae $/ 1000 \mathrm{~m}^{3}$
\end{abstract}

Key words: Abundance, diversity, fish larvae, Hurghada, Red Sea, Egypt

\section{INTRODUCTION}

Fish eggs and larvae represent the meroplanktonic stages of fishes that can be collected by planktonic gears and are found mainly in the upper 200 meters of the water column. They can be used to determine the geographical distribution of fishes (Leis, 1986, Leis \& McCormick, 2002) because they have a broader range than their reef sedentary demersal adult stages (Sale, 1980 \& 2002). They also serve to estimate the spawning stock, the spawning seasons and spawning grounds of the commercial fishes. Determination of the abundance of eggs and larvae in an area is usually less expensive to do than sampling the adults, because it is possible to sample several species over broad areas with a simple plankton net. Besides, the plankton samples contain not only the fish larvae but also part of their potential zooplanktonic prey and predator (Smith \& Richardson, 1977). 
Although the adult reef fishes of the tropical Indo-Pacific in general and the Red Sea in particular are well studied (Botros, 1971; Randall, 1983; Debelius, 1998), very little is known about their larval stages. There have been no previous studies on the larvae of coral reef fishes in the Red Sea. Literature describing the larval stages of coral reef fishes is also sparse or even lacking due to the identification difficulty. (Leis \& Rennis, 1983; Houde et al., 1986). Problems associated with the larval work can be summarized in taxonomy and sampling. Difficulties in identification stem from the fact that the pelagic stages of reef fishes are totally morphologically different from the adults. So, fish larvae are difficult to be identified that limited work on fish larvae has been done. Understanding of the fish biology can not be adequate unless the natural history and ecology of the larvae are well studied (Leis \& Rennis, 1983). So, the present study aimed to identify the larval stages of coral reef fishes and to investigate their diversity and abundance at Hurghada, Egyptian Red Sea.

\section{Sampling and preservation: \\ MATERIAL AND METHODS}

The environmental parameters of temperature and salinity were measured seasonally using a Hydro-Lab meter, Surveyor (4). Ichthyoplankton samples were taken monthly from January to December 2005 , using a $50 \mathrm{~cm}$ mouth diameter and $0.5 \mathrm{~mm}$ mesh size plankton net provided with a flowmeter to calculate the volume of water filtered. Nets were towed horizontally at $1 \mathrm{~m}$ depth near the reef edge for about 10 minutes with a towing speed of 1.5 knots. Samples were taken in the early morning just before sunrise and preserved immediately in buffered 5\% formalin seawater. Three replicates were taken where the mean abundance and mean volume of water were calculated. The volume of water filtered ranged from $64 \mathrm{~m}^{3}$ in April to $133 \mathrm{~m}^{3}$ in January (Table 1). Densities of fish larvae were standardised to $1000 \mathrm{~m}^{3}$ of water.

\section{Laboratory procedures:}

The samples were sorted and examined under an Olympus SZX7 stereomicroscope and then identified to the nearest possible taxonomic level, using the identification guides of Leis \& Rennis (1983), Abu El-Regal (1999), and classified according to Leis and Carson-Ewart (2002). All larvae were measured to the nearest $0.1 \mathrm{~mm}$ before final preservation in $70 \%$ ethanol.

\section{Data analysis:}

The univariate statistics were done in SPSS v.15.0, using ANOVA to determine differences in the numbers of individuals and number of species between months and sites. All data were tested for homogeneity of variance; when the samples were not homogeneous, data were either logarithmically or square root transformed or the non-parametric Kruskal-Wallis test was used 
(Zar, 1996; Dytham, 2003). The cluster analysis and diversity indices (species richness, evenness and Shannon-Wiener), were calculated using PRIMER v 5 after standardization and square root transformation.

\section{Study area:}

\section{RESULTS}

The study area at the northern part of Hurghada, on the Egyptian Red Sea was divided into inshore and offshore sites (Fig. 1). The inshore site is located directly in front of the Marine Biological Station (Table 2). It is a small area that extends to about $150 \mathrm{~m}$ seaward and ended with a lagoon of 5 $\mathrm{m}$ deep. The lagoon has sandy bottoms with algal mats and seagrass beds and is inhabited by many species of corals and fishes. The lagoon is followed by a reef flat with many coral species. The open sea adjacent to the reef flat descends to $12 \mathrm{~m}$ deep. Abu Sadaf is located about $1000 \mathrm{~m}$ away from the shore with a depth of from 1-2m. It is formed of many patches of corals that enclose some sandy areas, where the sampling process was carried out. Three sub-sites, sheltered side (H3), exposed side of the reef flat (X3) and Abu Sadaf (AS) were sampled. The second area, Giftun Islands, is a very popular diving site located about $15 \mathrm{~km}$ away from the Hurghada coast and includes extensive and diverse coral cover and fishes. Small Giftun (SG), Sabina 1 reef wall (X1, H1) and Sabina 2 reef wall (X2, H2), were sampled (Table 2).

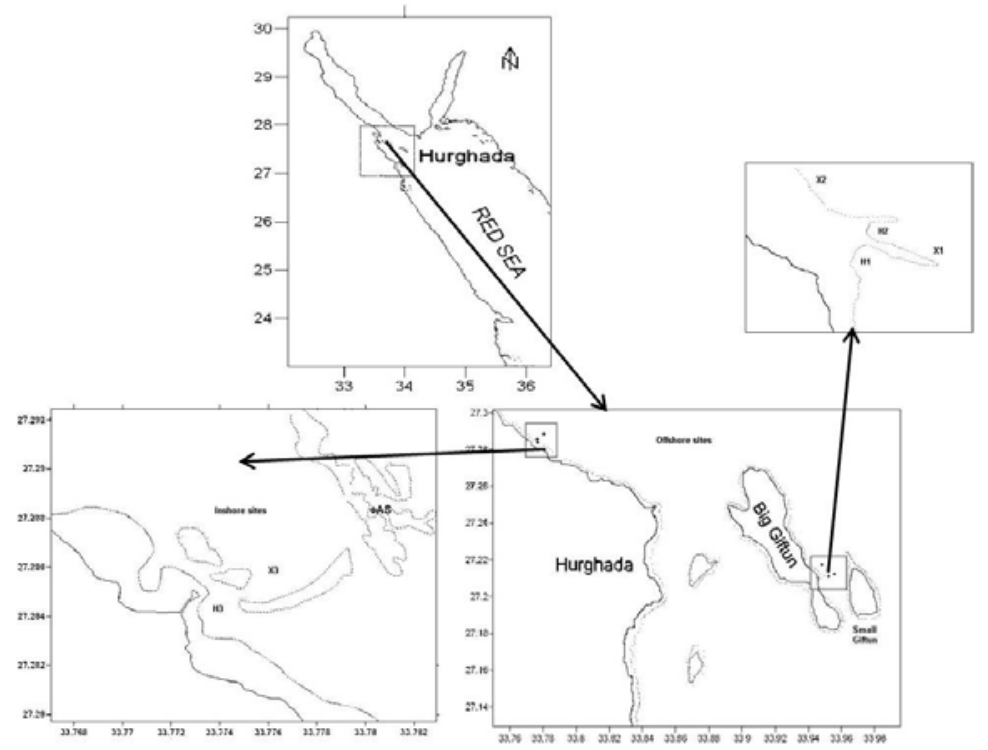

Fig.1. Map of the Red Sea, area of study and sampling sites 
Table (1) the mean abundance and the mean water volume at all sites. $\mathrm{SD}=$ standard deviation 


\section{Hydrographical conditions:}

Low variability in environmental conditions was observed among sites and seasons. The annual mean surface water temperature was $24.9^{\circ} \mathrm{C}$ offshore and $25.2^{\circ} \mathrm{C}$ inshore with the maximum during summer and early autumn (July-September) and the minimum during winter (January-March) The seasonal and regional distribution patterns of salinity showed very slight variations with a mean annual salinity of 39.8\%o offshore and 39.9\%o inshore (Table 3).

Table (2) Position and habitats of the sampling sites

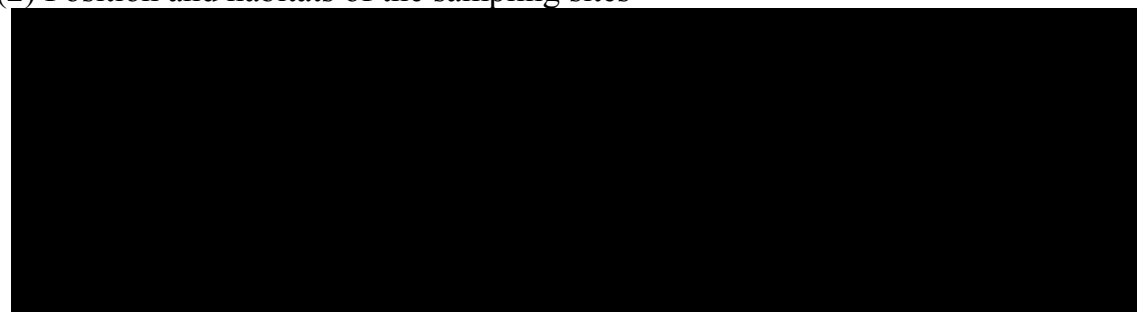

Table (3) Temperature and salinity at different sites on a bimonthly basis

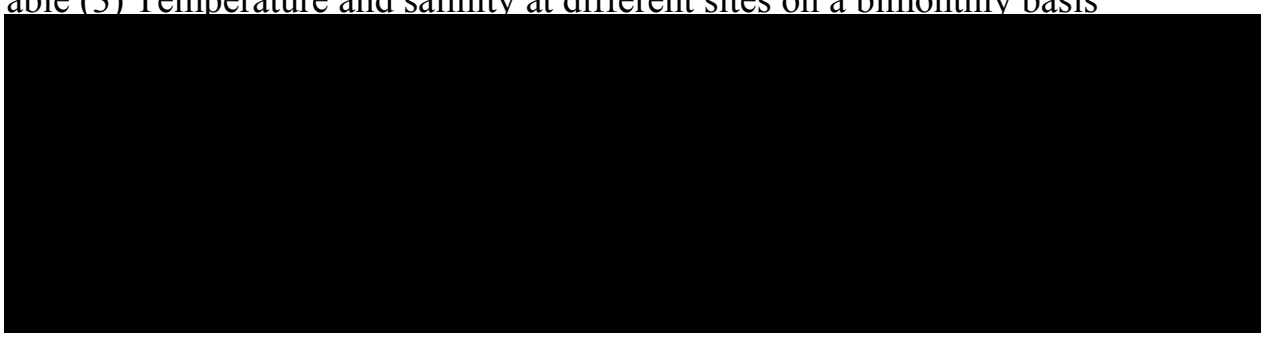

\section{Abundance of fish larvae:}

A total of 1799 larvae were collected from all sites throughout a year of sampling. The total abundance was 1993 larvae $/ 1000 \mathrm{~m}^{3}$. The abundance of fish larvae was high in late spring and summer (May-August) with the highest value in May (135 individuals $\left./ 1000 \mathrm{~m}^{3}\right)$, whereas the lowest abundance was in January (11 individuals $/ 1000 \mathrm{~m}^{3}$ ) (Fig.2). The analysis of ANOVA indicated a significant difference between months $(\mathrm{P}<0.05)$. The sheltered inshore $(\mathrm{H} 3)$ had the highest number of larvae with an average annual abundance of 253 individuals $/ 1000 \mathrm{~m}^{3}$. 


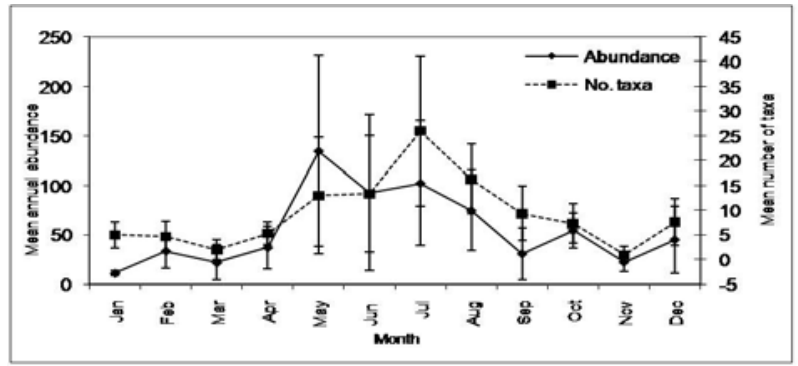

Figure (2). Monthly variation of larval fish abundance and number of taxa at all sites.

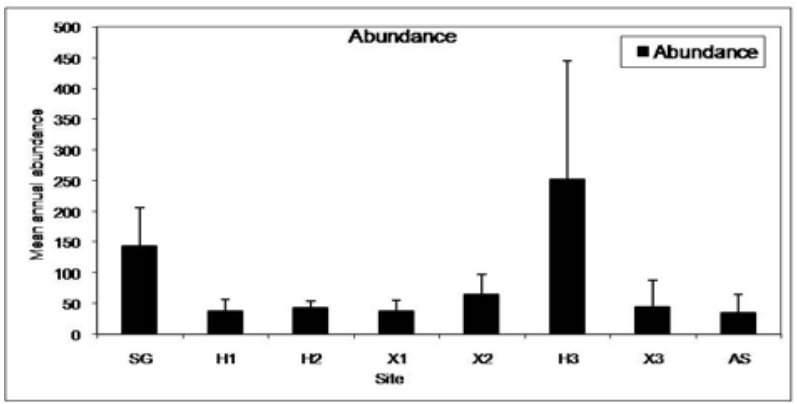

Fig. 3. The variation of larval fish abundance at different sites throughout the whole period of study.

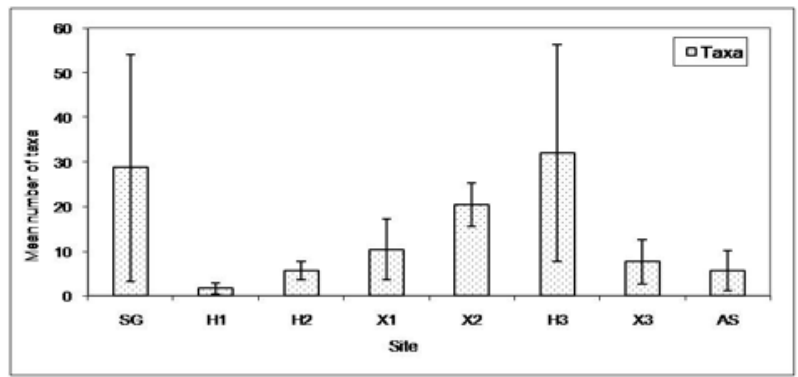

Figure (4). The regional variation of the number of taxa throughout the whole period of study

\section{Larval diversity:}

Throughout the whole period of study, larvae of 63 taxa belonging to 16 orders and 44 families of fish were identified. Most larvae could be identified to various taxonomic levels; 27 taxa were identified to the species level, 17 taxa to genus and 19 taxa as family. Approximately, $2.5 \%$ of the collected larvae could not be identified. 
Larvae of 25 taxa forming approximately $40 \%$ of all taxa collected were taken in July, recording the highest number of taxa, followed by May and June (21), and August (18). The lowest number of taxa (3) was recorded in November (Fig. 2).

The sheltered offshore site, H3 and the offshore site SG had the highest number of species where 31 and 28 taxa respectively followed by site X2 (23). The sheltered offshore sites H1 (5 taxa) and H2 (4 taxa) were very poor in diversity (Fig. 4). Regarding the number of taxa, there was a significant difference among sites $(\mathrm{F}=12.8 \mathrm{P}<0.01)$ and months $\left(\chi^{2}=33.5 \mathrm{P}<0.05\right)$.

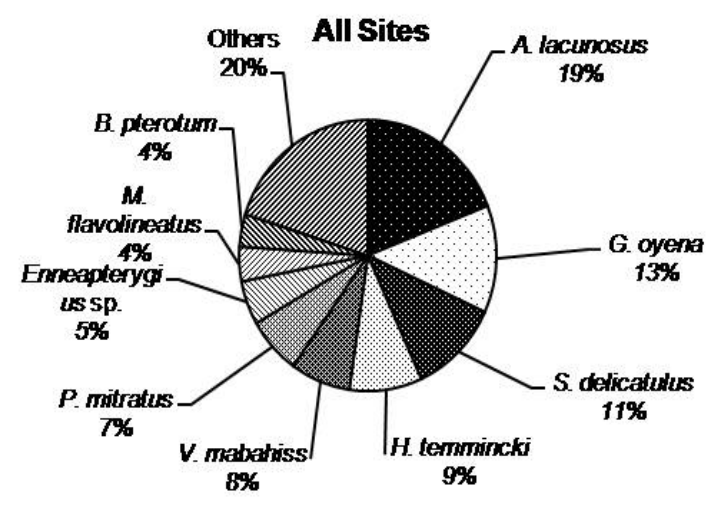

Figure (5). Percentage contribution of the most abundant taxa at all sites and months

The most diverse order was the Perciformes which contained 22 families and 34 taxa. The most abundant 10 taxa identified were Atherinomorus lacunosus (Atherinidae), Spratelloides delicatulus (Clupeidae), Gerres oyena (Gerreidae), Hypoatherina temmincki (Atherinidae), Petroscirtes mitratus (Blennidae), Vinciguerria mabahiss (Phosichthyidae), Enneapterygius sp. (Triptrygiidae), Mulloides flavolineatus (Mullidae), Benthosema pterotum (Myctophidae) and Gobiidae, forming about $82.5 \%$ of all larvae. Larvae of Atherinomorus lacunosus were the most abundant, contributing about $19 \%$ of all taxa with a total abundance of $1 / \mathrm{r}$ larvae $/ 1000 \mathrm{~m}^{3}$, followed by Spratelloides delicatulus and Gerres oyena that constituted $12.1 \%$ and $11.9 \%$ respectively (Fig.5). Larvae of families Siganidae and Soleidae were the least abundant, with 0.23 larvae $/ 1000 \mathrm{~m}^{3}$ each (Table 4). 


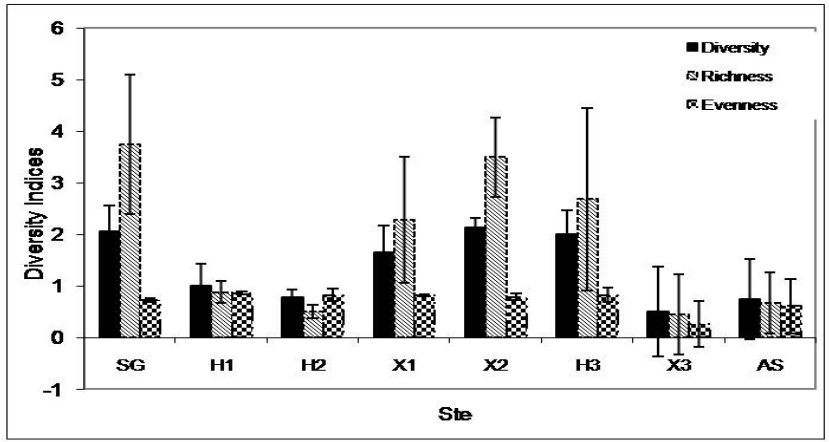

Figure (6). The regional variation of diversity indices (diversity, richness and evenness).

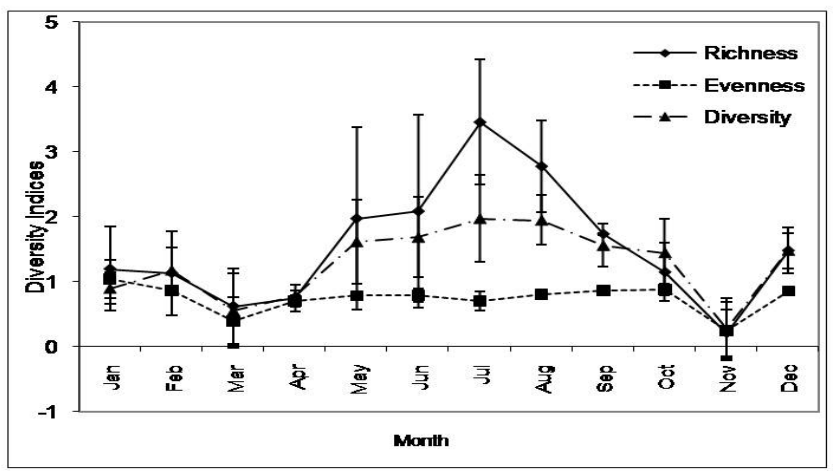

Figure (7). Seasonal variations of the diversity indices (species richness, evenness and species diversity). 
Table (4) Mean annual abundance of different fish larval taxa at different sites SD= standard deviation

\section{DISCUSSION}

Fishes of the Red Sea, have been extensively studied (e.g. Gohar, 1948; Gohar and Latif, 1959; Al-Kholy, 1964; Botros, 1971; Randall, 1983; Ormond and Edwards, 1987; Ahmed, 1992; El-Etreby et al. 1993; El-Etreby et al. 1999). A comprehensive checklist of Red Sea species was published by Goren \& Dor 
(1994). However, ichthyoplankton has been scarcely studied in the Red Sea (Nellen, 1973; Abu El-Regal, 1999; Faroukh, 2001). The lack of literature on larval systematics in the Red Sea made the ichthyoplankton identification task even more difficult than had been anticipated. There is a critical need for careful taxonomic studies on the larvae to help in future research in the Red Sea. Knowledge of the ichthyoplankton can be useful in estimating the size of a spawning stock and in determining the spawning seasons and spawning grounds of the commercial fishes, and is urgently needed as a tool for management of the Red Sea fisheries and coral reef-associated fishes.

Despite differences in sampling methods, the present study confirmed the highest abundance of fish larvae from May to August as reported for the northern Red Sea (El-Sherbiny, 1997; Abu El-Regal, 1999; Faroukh, 2001). The larval abundance and predominant taxa were similar to that reported in Sharm El-Sheikh (Abu El-Regal, 1999), although fish families (44) were collected during the present study than those from Sharm El-Sheikh (32) (Abu El-Regal, 1999) and from Aqaba (25) (Faroukh, 2001). Larvae of some families such as Pomacanthidae, Scaridae, Microdesmidae, Gerreidae and Engraulidae were found only at Hurghada but were not detected from Sharm El-Sheikh and Aqaba (Abu El-Regal, 1999; Faroukh, 2001). Of the most abundant families in Aqaba; Clupeidae, Pomacentridae, Apogonidae and Gobiidae (Faroukh, 2001), only Clupeidae was dominant in the present work. Similarity in species composition of fish larvae between Sharm El-Sheikh and Hurghada could be due to the similar environmental conditions while differences may be due the different sampling techniques.

In the current work, most collected larval fish taxa were reported as adults in the Red Sea. Most notably, larvae of some families of reef fishes were missing in the area of study although they occur in the area as adults. Similarly, many studies reported adults of various fish families but did not find their larvae (Miller, 1974, 1979; Watson \& Leis, 1974; Young et al., 1986) in Great Barrier Reef in Australia. Leis (1994) considered it possible that pelagic larvae of many coral reef fishes disperse from their natal reef. Hence the inshore larval assemblages may not be fully representative of the adult fish assemblage. Many of the missing reef fish larvae inshore were found $5-12 \mathrm{~km}$ offshore in Hawaiian waters (Leis \& Miller, 1976). Thus, fish larvae originating from a fish population on a given reef are not necessarily retained near that reef; and can lead to the rarity or absence of larvae of some of the coral reef fishes from the area.

Chaetodontidae, Scaridae and Lutjanidae have a very short planktonic life (Lowe-McConnell, 1979). Jones et al., (2005) found that larvae of the pomacentrid Amphiprion polymnus have a larval duration of 9-12 days that is shorter than that of other coral reef fishes. They expected that this species has a very short dispersal time from the natal reef. On the other hand, some larval stages have very long larval duration. In the present work, leptocephali were 
very rare in the collection and could not reflect the eel's assemblages in the area. The vast majority of leptocephali larvae simply avoid the net due to their large size and excellent swimming ability both forward and backward, making them well adapted to avoid small plankton nets. Their large eyes enable them to avoid nets at the day light. Leptocephali can be taken in large number only at night. The best plankton net for collecting leptocephali appears to be the Isaacs Kidd Midwater Trawl (Miller et al., 2006).

The larval fish assemblages in coastal tropical waters are the result of spawning activities of reef fish, and open water fish that is dominated by mesopelagic fishes (Ahlstrom, 1971; 1972; Leis \& Goldman, 1987). Larvae of 35 coral reef fish families were collected in the present study, of which 21 families were taken from inshore and 28 were taken from offshore. Surprisingly, larval mesopelagic fishes are abundant near the coral reef and this is in agreement with the findings of Leis (1991a) who concluded that mesopelagic larvae may be brought to the reef by water currents.

The distribution of fish larvae can be influenced by the environmental conditions (Hernández-Miranda et al., 2003). In the present study, there were no significant differences in water salinity and temperature between different sites, but between seasons. Hence temperature may influence the temporal but not the spatial distribution of fish larvae in the Red Sea. The highest catch and taxon richness of fish larvae in summer may be due to high temperatures in the area of study during summer. The abundance and location of larvae may be strongly related to the habitat type and/or spawning ground of the adult. These correspond to areas that favour the subsequent coupling between spawned cohorts and the presence of food (Cushing, 1990). Indo-Pacific coral reefs, including the Red Sea, have a complex topography, hydrography and biota. The structural complexity of coral reefs provides a variety of habitats, most of which support fish larvae (Leis, 1991b).

At the inshore sites, larvae were more abundant and diverse on the sheltered side than the exposed side. In contrast, the offshore sites had larger numbers of larvae and species on the exposed sides. Most collected larvae from the offshore exposed sites hatched from pelagic spawners, whereas the majority of fish larvae in the offshore sheltered sites hatched from demersal eggs. This is consistent with results of other studies, where larval fish assemblages inshore were dominated by larvae from demersal spawners (Leis 1982; Smith et al., 1987; Suthers \& Frank, 1991; Leis \& McCormic, 2002; Paris and Cowen, 2004).

Most of the larval fish taxa collected during the current study are commercially important such as Mullidae, Lutjanidae, Scaridae, Carangidae, Sphyraenidae, Gerreidae and Serranidae, which are the major constituents of fishery in the Red Sea in general and Hurghada in particular. Other larvae were belonging to ornamental fishes that can be used in aquarium trade and as game fishes and reef recreations such as diving and snorkling that are the backbone of tourism industry in the area. The culture of marine tropical fish conserves natural 
reef resources by offering alternatives to wild capture and develops a new source of organisms for the aquarium trade. Although many of the fresh water tropical species sold to the public are now cultured, more than $90 \%$ of all marine tropical ornamental organisms continued to be collected from the wild.

\section{REFERENCES}

Abu El-Regal, M. A. (1999). Some biological and ecological studies on the larvae of coral reef fishes in Sharm El-Sheikh (Gulf of Aqaba-Red Sea). M.Sc. Thesis. Marine Science Department, Faculty of Science Suez Canal University, 167 pp.

Ahlstrom, E. H. (1971). Kinds and abundance of fish larvae in the eastern tropical Pacific, based on collections made on EASTROPAC I. Fish. Bull., 69(1): 3-77.

Ahlstrom, E. H. (1972). Kinds and abundance of fish larvae in the eastern tropical Pacific on the second multivessel EASTROPAC survey and observations on the annual cycle of larval cycle of larval abundance. Fish. Bull., 70(4): 1153-1242.

Ahmed, A. E. (1992). Ecological and Biological studies on juvenile fishes in South Sinai. M.S. Thesis. Marine Science Department, Faculty of Science, Suez Canal University. Egypt., 120 pp.

Al-Kholy, A. (1964). Red Sea Fisheries. General Egyptian Organization of Aquatic Resources. Cairo., 345 pp.

Botros, G. A. (1971). Fishes of the Red Sea. Oceanography and Mar. Biol. An Annual Review. 9: 221-348

Cushing, D. H. (1990). Plankton production and year class strength in fish populations: an update of the match/mismatch hypothesis. In: Blaxter, J. H., Southward, A. J. (Eds.), Advances in Marine biology, vol. 26. Academic Press, San Diego, pp. 249-293.

Debelius, H. (1998). Red Sea reef guide. IKAN-Unterwasserarchiv. Frankfurt. $321 \mathrm{pp}$.

Dytham, C. (2003). Choosing and using statistics. A biologist's guide. Blackwell Publishing, Oxford, 248pp. 
El-Etreby, S.G.; Roberts, C.M.; Ghobashy, A.A and Zyadah, M.A. (1993). Coral Reef Groupers ( Family Serranidae ) in South Sinai.II. Growth, Food and Feeding Habits of the Fish Cephalopholis hemistiktos ( Ruppell, 1830 ). J. Egypt. Ger. Soc. Zool., 11(B): 57-72.

El-Etreby S.G.; Hanafy, M.H.; Abu-Zeid, M.M. and El-Alwany, M.A. (1999). Distribution of Butterflyfishes ( Chaetodontidae ) and Angelfishes ( Pomacanthidae ) on the western coast of Gulf of Aqaba, northern Red Sea. Second Symposium on "The Red Sea Marine Environment" Faculty of Marine Science, Jeddah, Saudi Arabia.

El-Sherbiny, M. M. (1997). Some ecological studies on zooplankton studies in Sharm El-Sheikh area (Red Sea). M. Sc. Thesis. Mar. Sci. Dept. Fac. Sci. Suez Canal University. Egypt. 151 pp.

Faroukh, T. J. (2001). Studies on taxonomy and ecology of some fish larvae from the Gulf of Aqaba. M.Sc. Thesis. Fac. of Graduate Studies. Univ. of Jordan. $103 \mathrm{pp}$.

Gohar, H. A. F. (1948). On the relation between fish and anemone with a description of eggs of Amphiprion bicinctus (Rüppell). Publication of the Marine Biological Station, Al-Ghardaqa, Red Sea, 6: 35-44.

Gohar, H. A. F. and Latif, F. A. (1959). Morphological studies on the some scarid and labrid fishes. Publ. Mar. Biol. Station., Al-Ghardaqa, Red Sea, 10:145-190.

Goren, M. and Dor, M. (1994). An updated checklist of the fishes of the Red Sea CLOFRESII. Israel Academy for Sciences and Humanities. The Israel Academy of Sciences and Humanities. Jerusalem, 120 pp.

Hernández-Miranda, E.; Palm, A.T. and Ojeda, E. P. (2003). Larval fish assemblages in nearshore coastal waters off central Chile: temporal and spatial patterns. Estuar. Coast. Shelf. Sci., 56: 1075-1092.

Houde, E. D.; Almatar, S.; Leak, J. C. and Dowd, C.E. (1986). Ichthyoplankton abundance and diversity in the Western Arabian Gulf. Kuwait Bull. Mar. Sci., 8:107-393.

Jones, G.P.; Planes, S. and Thorrold, R. (2005). Coral reef fish larvae settle close to home. Curr. Biol., 15: 1314-1318. 
Leis, J. M. (1982). Nearshore distributional gradients of larval fish (15 taxa) and planktonic crustaceans (6 taxa) in Hawaii. Mar. Biol., 77: 89-97.

Leis, J. M. (1986). Vertical and horizontal distribution of fish larvae near coral reefs at Lizard Islands, Great Barrier Reef. Mar. Biol., 90:505-516

Leis, J. M. (1991a). The pelagic stage of reef fishes: The larval biology of coral reefs. In: Sale, P. F. the ecology of fishes on coral reefs. Academic press,. pp 183-230

Leis, J. M. (1991b). Vertical distribution of fish larvae in the Great Barrier Reef lagoon, Australia. Mar. Biol., 109:157-166.

Leis, J. M. (1994) Coral Sea atoll lagoons: closed nurseries for the larvae of coral reef fishes. Bulletin of Marine Science., 54(1): 6-227.

Leis, J. M. and Carson-Ewart, B. M. (2002). Larvae of Indo-Pacific coastal fishes. An identification guide to marine fish larvae. (Fauna Malesiana Handbooks 2). E. J. Brill, Leiden, 850 pp.

Leis, J. M. and Goldman, B. (1987). Composition and distribution of larval fish assemblages in the Great Barrier Reef Lagoon near Lizard Island, Australia. Australian Journal of Marine and Freshwater Research, 38(2):211-223.

Leis, J. M. and McCormick, M. I. (2002). The biology, behaviour, and ecology of the pelagic larval stage of coral reef fishes. In: Sale, P.F. (Ed), Coral reef fishes: dynamics and Diversity in a complex ecosystem. Academic press, San Diego. pp. 171-199.

Leis, J. M. and Miller, J. M. (1976). Offshore distributional patterns of Hawaiian fish larvae. Mar. Biol., 36(3): 359-367.

Leis, J. M. and Rennis, D. S. (1983). The larvae of Indo-Pacific coral reef fishes. New South Wales Univ. Press, Sydney, Australia. 269 pp.

Lowe-McConnell, R. H. (1979). Ecological aspects of seasonality in fishes of tropical waters. Symp. Zool. Soc. London, 44: 219-241

Miller, J. M. (1974). Nearshore distribution of Hawaiian marine fish larvae: effects of water quality, turbidity and currents. In: "the early life 
history of fish" (J. H. S. Blaxter, ed), pp. 217-231. Springer-Verlag, New York.

Miller, J. M., (1979). Larval fish distribution. In" an atlas of common nearshore fish larvae of the Hawaiian Islands" (J.M. Miller, W. Watson and J.M. Leis), Misc. rep. 80-02,pp 105-152. Univ. of Hawaii Sea Grant program, Honolulu, Hawaii.

Miller, M. J.; Aoyama, J.; Mochioka, N.; Otake, T.; Castle, P.H.J.; Minagawa, G.; Inagaki, T. and Tsukamoto, K. (2006). Geographical variation in the assemblages of leptocephali in the western South pacific. Deep Sea Research, 1(53): 776-794

Nellen, W. (1973). Kinds and abundance of fish larvae in the Arabian Sea and the Persian Gulf In: B. Zeitzschel. Ed. The biology of the Indian Ocean. New York. 523 pp. Verlag, pp. 415- 430.

Ormond, R. F. and Edwards, G. A. (1987). Red Sea Fishes. Red Sea (Key Environments) (eds. By A. J. Edwards and S. M. Head), pp. 251287. Pergamon Press, Oxford.

Paris, C. and Cowen, R. k. (2004). Direct evidence of biophysical retention mechanism for coral reef fish larvae. Limnology and Oceanography, 49: 1964-1979.

Randall, J. (1983). Red Sea Reef Fishes. IMMEL Publishing, London. 192 pp.

Sale, P. F. (1980). The ecology of fishes on coral reefs. Oceanography and Marine Biology, 18: 367-421

Sale, P. F. (2002). Coral reef fishes: dynamics and Diversity in a complex ecosystem. Academic Press, San Diego.

Smith, C. L.; Tyler, J. C. and Stillman, L. (1987). Inshore ichthyoplankton: a distinctive assemblage? Bulletin of Marine Science, 41: 432-440.

Smith, P. E. and Richardson, S. L. 1977. Standard techniques of pelagic eggs and larvae surveys. FAO Fish. Tech. Pap., 175:1-100.

Suthers, M. and Frank, K. T. 1991. Comparative persistence of marine fish larvae from pelagic versus demersal eggs off south-western Nova Scotia, Canada. Mar. Biol., 108:175-184 
Watson, W. and Leis, J. M. (1974). Ichthyoplankton of Kaneohe Bay, Hawaii: a one-year study of fish eggs and larvae. Univ. Hawaii Sea Grant Program Technical Report 75-01, 178 pp.

Young, P. C.; Leis, J. M. and Hausfeld, H. F. (1986). Seasonal and spatial distribution of fish larvae in waters over the North West Continental Shelf of Western Australia. Marine Ecology Progress. Series, 31: 209-222.

Zar, J. H. (1996). Biostatistical analysis. Fourth Edition. Prentice Hall International (UK), London. 